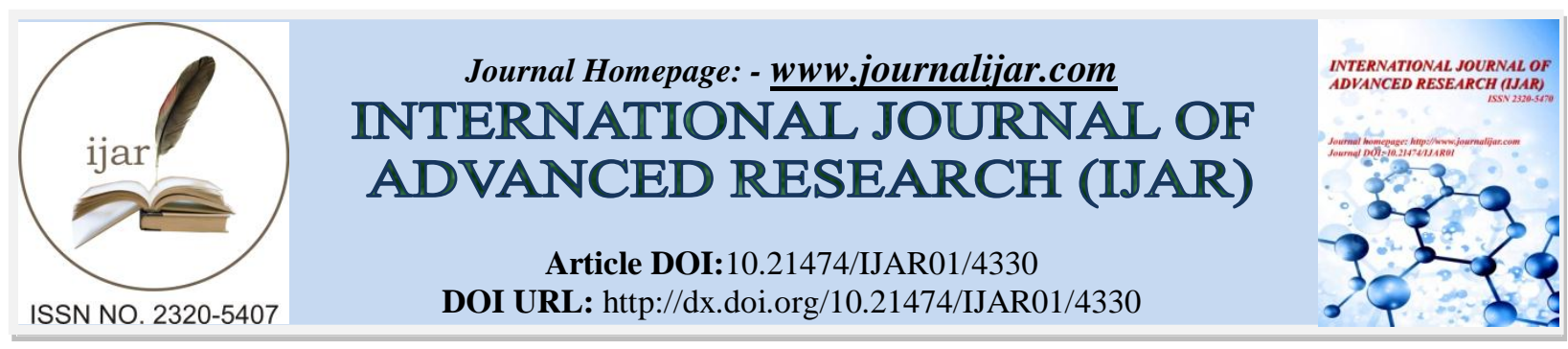

RESEARCH ARTICLE

\title{
A COMPREHENSIVE STUDY AMONG THE WORKING WOMEN TOWARDS THE AWARENESS OF TAX SAVING SCHEMES IN ALLAHABAD.
}

\begin{abstract}
Dr. AbhishekJanvier Frederick ${ }^{1}$, Dr. Sebastian .T. Joseph ${ }^{2}$ and Mr.Jonathan Joe Pereria ${ }^{3}$.
1. Assistant Professor Joseph School of Business Studies Sam Higginbottom University of Agriculture, Technology \& ScienceAllahabad,Uttar Pradesh

2. Sr. Assistant Professor Joseph School of Business StudiesSam Higginbottom University of Agriculture, Technology \& Sciences Allahabad,Uttar Pradesh

3. MBA Student $4^{\text {th }}$ Semester, Joseph School of Business StudiesSam Higginbottom University of Agriculture, Technology \& Sciences.
\end{abstract}

\section{Manuscript Info}

Manuscript History

Received: 26 March 2017

Final Accepted: 30 April 2017

Published: May 2017

Key words:-

Tax saving, Investment pattern, Liability.

\section{Abstract}

Government has to play an important role in all round development of society and country as a whole. Tax constitutes the main source of finance whereby government raises revenues for public spending. In India income tax contributes to up to $52.28 \%$ (14-15MOF) to the total revenue of government. Because of compulsion element each tax payer faces the problem of how to find golden ways to minimize their tax liabilities. But paying tax is always a painful task as it directly impacts on the residual income of the taxpayer. So, all individual always try to reduce tax liability by managing their financial affairs. Tax planning is important for every assesse to reduce their tax liability and compliance with the income tax rule. To enjoy the benefits of tax planning the assesse must know different provisions of tax savings schemes available in the law. This paper studies the awareness of working women, towards tax benefits schemes and the investment pattern towards tax benefits schemes in Allahabad.

Copy Right, IJAR, 2017,. All rights reserved.

\section{Introduction:-}

The status of women in India has been subject to many great changes over the past few millennia. With a decline in their status from the ancient to medieval times, to the promotion of equal rights by many reformers, the history of women in India has been eventful. In modern India, women have held high offices including that of the President, Prime Minister, Speaker of the LokSabha, Leader of the Opposition, Union Ministers, Chief Ministers, and Governors. Women's rights are secured under the Constitution of India - mainly, equality, dignity, and freedom from discrimination; further, India has various statutes governing the rights of women. As of 2011, the President of India, the Speaker of the LokSabha and the Leader of the Opposition in the LokSabha (Lower House of the parliament) were women. However, women in India continue to face numerous problems, including violent victimization through rape, acid throwing, dowry killings, marital rape, and the forced prostitution of young girls. In 2012, the Thomson Reuters Foundation ranked India as the worst G20 country in which to be a woman.

Women's empowerment has become a significant topic of discussion in development and economics. It can also point to approaches regarding other trivialized genders in a particular political or social context. Women's economic 
empowerment refers to the ability for women to enjoy their rights to control and benefit from resources, assets, income and their own time, as well as the ability to manage risk and improve their economic status and well-being. While often interchangeably used, the more comprehensive concept of gender empowerment refers to people of any gender, stressing the distinction between biological sex and gender as a role. It thereby also refers to other marginalized genders in a particular political or social context.

Tax Saving Schemes in India, the quantum of Income Taxes can be somewhat reduced by investing smartly in tax saving schemes. There are multiple opportunities to reduce an individual's tax burden by using the available schemes appropriately. There are various sections of the Income Tax Act, 1961 which deal with tax deductions and exemptions such as Section 80C, 80D, 80CCF, and others. Many government and private sector organizations provide a wide range of tax-saving options for Indian residents.

\section{Review of Literature:-}

The results from many studies has focused that women are better manager than men but when the question comes of financial management, they rely on their counterparts. Studies has shown that women professional has basic knowledge of financial transaction, but they are still financially illiterate on the concepts of Money Management and Investment (Sebastian \& Appalla Raju,2016.). (Jisha, Go Mathi, Professor, \& Scholar, 2017) identified the relationship between the factors influencing the level of awareness of various investment and factors influencing the benefits. Investors describe safety of funds as their priority for choosing an investment. (By \& Jain pursuing, 2014) found in their study is that most important reason why a woman saves is because of a "Precautionary" motive. (Palil, Rusyidi, Akir, Fadillah, \& Ahmad, 2013) results of the study suggested that religious values play a very important role to make the taxpayer liable for tax compliance. Moral and ethical values distinguish each offense towards not tax compliant as a sin nd should be avoided.

\section{Need of the Study:-}

Women have been contributing in our society in different walks of life like, education, household, medicine, corporate sector and legal and mass communication etc. But when the question of handling, their own hard earned income or family income arises, the onus is transferred to their male counterparts. The matters of investment, future financial planning and investment for tax benefits are generally taken care by the male members of the family.

But in the present scenario there is a need for understanding the complexities of finance by female study, therefore to target this need the present study is being conducted to measure the awareness of working women in related to Tax saving schemes.

\section{Objectives of the Study:-}

1. To study the awareness of working women, towards tax benefits schemes.

2. To study the investment pattern of working women towards tax benefits schemes.

\section{Hypothesis of the study:-}

The following are the hypothesis of the study:

- Null Hypothesis $\left(\mathbf{H}_{\mathbf{0}}\right)$ : There is a significant difference among the working women towards the awareness of tax saving schemes in Allahabad

- Alternative Hypothesis $\left(\mathbf{H}_{\mathbf{1}}\right)$ : There is no significant difference among the working women towards the awareness of tax saving schemes in Allahabad.

\section{Research Methodology:- \\ Area of the study:-}

- $\quad$ The study is being conducted in the Allahabad district of Uttar Pradesh State.

\section{Research Design:-}

The present study is focused on the exploratory research design.

\section{Data used:-}

The primary data has been the modus operandi for exploring the respondent's awareness, the secondary data has been the base on which the study stands. 


\section{Data Source:-}

The primary data for the study has been collected from respondent's who are employed, with the help of personal interview method to know their awareness.

\section{Sample population:-}

In this study the respondents are the women working in different sectors from different age group.

\section{Sample size:-}

The sample for the study was 110 respondents with minimum qualification of HSC and maximum Post graduate.

\section{Primary data source:-}

The primary data for the study was collected from the respondents by personal interview method using pretested schedule. The primary data collected was based on the memory of the respondents.

\section{Sample area:-}

The study was conducted in Allahabad district of Uttar Pradesh. Allahabad district is sub divided into Allahabad East and Allahabad West according to the local governing body i.e. nagarnigam.

\section{Period of study:-}

The study had been conducted from commencing from $1{ }^{\text {st }}$ December 2016 to $28^{\text {th }}$ Feb 2017 and completed in a period of three months.

\section{Results \& Discussions:-}

Table 1.1:-

\begin{tabular}{|l|l|r|r|r|r|}
\hline \multicolumn{5}{|c|}{ Do you know under which tax slab you fall? } \\
\hline \multirow{3}{*}{ Valid } & $0-250000$ & Frequency & Percent & Valid Percent & Cumulative Percent \\
\cline { 2 - 6 } & $251000-500000$ & 45 & 40.9 & 40.9 & 40.9 \\
\cline { 2 - 6 } & $500001-100000$ & 29 & 26.4 & 26.4 & 67.3 \\
\cline { 2 - 6 } & 1000000 and Above & 34 & 30.9 & 30.9 & 98.2 \\
\cline { 2 - 6 } & Total & 2 & 1.8 & 1.8 & 100.0 \\
\hline
\end{tabular}

The Table 1.1 depicts that, the highest percentage of respondents $40.9 \%$ i.e., fall under $0-2,50,000$ tax slab, whereas the minimum respondents were from $10,00,000$ and above i.e., only $1.82 \%$.

Table 1.2:-

\begin{tabular}{|c|c|c|c|c|c|}
\hline \multicolumn{6}{|c|}{ If no, then would you like to know about it? } \\
\hline & & Frequency & Percent & Valid Percent & Cumulative Percent \\
\hline \multirow[t]{3}{*}{ Valid } & Yes & 35 & 31.8 & 31.8 & 31.8 \\
\hline & No & 75 & 68.2 & 68.2 & 100.0 \\
\hline & Tota & 110 & 100.0 & 100.0 & \\
\hline
\end{tabular}

The Table no. 1.2 depicts, that 31.8\% respondents were not aware from the tax slab in which their income is falling and they were ready to know about it, while a major chunk of $68.2 \%$ were not interested to know about the tax slabs.

Table 1.3:-

\begin{tabular}{|l|l|r|r|r|r|}
\hline \multicolumn{7}{|c|}{ Are you a regular tax payer? } \\
\hline \multirow{3}{*}{ Valid } & Yes & Frequency & Percent & Valid Percent & Cumulative Percent \\
\cline { 2 - 6 } & No & 84 & 76.4 & 76.4 & 76.4 \\
\cline { 2 - 6 } & Total & 26 & 23.6 & 23.6 & 100.0 \\
\hline
\end{tabular}

The Table no. 1.3 depicts, that $76.4 \%$ of respondents were regular tax payers and $23.6 \%$ were not. 
Table 1.4:-

\begin{tabular}{|c|c|c|c|c|c|}
\hline \multicolumn{6}{|c|}{ Do you know how much rate of tax are you paying? } \\
\hline & & Frequency & Percent & Valid Percent & Cumulative Percent \\
\hline \multirow[t]{5}{*}{ Valid } & $5 \%$ & 31 & 28.2 & 28.2 & 28.2 \\
\hline & $10 \%$ & 21 & 19.1 & 19.1 & 47.3 \\
\hline & $30 \%$ & 6 & 5.5 & 5.5 & 52.7 \\
\hline & Don't know & 52 & 47.3 & 47.3 & 100.0 \\
\hline & Total & 110 & 100.0 & 100.0 & \\
\hline
\end{tabular}

The Table 1.4 depicts that, the $47.3 \%$ percentage of respondents were not aware of the fact that what tax rate is been charged on their income, which is quite a number.

Table 1.5:-

\begin{tabular}{|c|c|c|c|c|c|}
\hline \multicolumn{6}{|c|}{ If no, would you like to know the rate you are paying? } \\
\hline & & Frequency & Percent & Valid Percent & Cumulative Percent \\
\hline \multirow[t]{3}{*}{ Valid } & Yes & 29 & 55.76 & 55.76 & 55.76 \\
\hline & No & 23 & 44.23 & 44.23 & 100.0 \\
\hline & Total & 52 & 100.0 & 100.0 & \\
\hline
\end{tabular}

The Table no. 1.5 depicts, that out of 52 respondents questioned in Table 1.4 who were not aware of tax rate applicable to them, $55.76 \%$ respondents were ready to know about I and still $44.23 \%$ respondents were reluctant to know.

Table 1.6:-

\begin{tabular}{|c|c|c|c|c|c|}
\hline \multicolumn{6}{|c|}{ Do you think that the tax slab has gender discriminations? } \\
\hline & & Frequency & Percent & Valid Percent & Cumulative Percent \\
\hline \multirow[t]{3}{*}{ Valid } & Yes & 51 & 46.4 & 46.4 & 46.4 \\
\hline & No & 59 & 53.6 & 53.6 & 100.0 \\
\hline & Total & 110 & 100.0 & 100.0 & \\
\hline
\end{tabular}

The Table 1.6 depicts that, 53.64\% respondents think there is no gender discrimination. Whereas the $46.36 \%$ respondent thinks there is gender discrimination.

Table1.7:-

\begin{tabular}{|c|c|c|c|c|c|}
\hline \multicolumn{6}{|c|}{ Under which head of income, your income becomes taxable? } \\
\hline & & Frequency & Percent & Valid Percent & $\begin{array}{c}\text { Cumulative } \\
\text { Percent }\end{array}$ \\
\hline \multirow[t]{5}{*}{ Valid } & income from salary & 87 & 79.1 & 79.1 & 79.1 \\
\hline & income from house property & 8 & 7.3 & 7.3 & 86.4 \\
\hline & $\begin{array}{l}\text { profit and gains of business, } \\
\text { professional }\end{array}$ & 8 & 7.3 & 7.3 & 93.6 \\
\hline & $\begin{array}{l}\text { capital gains income from } \\
\text { other sources }\end{array}$ & 7 & 6.4 & 6.4 & 100.0 \\
\hline & Total & 110 & 100.0 & 100.0 & \\
\hline
\end{tabular}

The Table 1.7 depicts that, the highest percentage of respondents say that $79.09 \%$ i.e., income from salary becomes taxable, while the minimum respondents were from capital gain income from other sources i.e., only $6.36 \%$.

Table 1.8:-

Did you know that income tax act undergoes changes every year with additional and deletions brought about by the finance act passed by parliament (

\begin{tabular}{|c|c|c|c|c|c|}
\hline & & Frequency & Percent & Valid Percent & Cumulative Percent \\
\hline \multirow[t]{3}{*}{ Valid } & yes & 74 & 67.3 & 67.3 & 67.3 \\
\hline & No & 36 & 32.7 & 32.7 & 100.0 \\
\hline & Total & 110 & 100.0 & 100.0 & \\
\hline
\end{tabular}

The Table no. 1.8 depicts, $67.3 \%$ respondents were aware from the question of annual modification to the tax act, while $32.7 \%$ were not aware. 
Table 1.9:-

Do you know the various items (agricultural income, gratuities, LIC, payment from PF, amount received by way of gifts, share from partnership firms) that are exempt from tax?

\begin{tabular}{|c|c|c|c|c|c|}
\hline & Frequency & Percent & Valid Percent & Cumulative Percent \\
\hline \multirow[t]{3}{*}{ Valid } & Yes & 75 & 68.2 & 68.2 & 68.2 \\
\hline & No & 35 & 31.8 & 31.8 & 100.0 \\
\hline & Total & 110 & 100.0 & 100.0 & \\
\hline
\end{tabular}

The Table no. 1.9 depicts, $68.2 \%$ respondents were aware about various incomes which are exempted from tax, while $31.8 \%$ did not know about it.

Table 1.10

\begin{tabular}{|c|c|c|c|c|c|}
\hline \multicolumn{6}{|c|}{ Do you know deductions permissible under chapter VI-A of income tax act, 1961 (NSC, LIC, PF)? } \\
\hline & & Frequency & Percent & Valid Percent & Cumulative Percent \\
\hline \multirow[t]{3}{*}{ Valid } & Yes & 57 & 51.8 & 51.8 & 51.8 \\
\hline & No & 53 & 48.2 & 48.2 & 100.0 \\
\hline & Total & 110 & 100.0 & 100.0 & \\
\hline
\end{tabular}

The Table no. 1.10 depicts, $51.8 \%$ respondents were aware about various deductions which are deductions permissible under chapter VI-A of income tax act, 1961 while $48.2 \%$ did not know about it.

Table 1.11:-

\begin{tabular}{|c|c|c|c|c|c|}
\hline \multicolumn{6}{|c|}{ Are all the taxpayers obliged to submit a tax return? } \\
\hline & & Frequency & Percent & Valid Percent & Cumulative Percent \\
\hline \multirow[t]{3}{*}{ Valid } & Yes & 92 & 83.6 & 83.6 & 83.6 \\
\hline & No & 18 & 16.4 & 16.4 & 100.0 \\
\hline & Total & 110 & 100.0 & 100.0 & \\
\hline
\end{tabular}

The Table no. 1.11 depicts83.6\% respondents were aware that all the tax payers have to file their tax return, while only $16.4 \%$ did not know about it.

Table 1.12:-

\begin{tabular}{|c|l|r|r|r|r|}
\hline \multicolumn{9}{|c|}{ Is there any penalty for incorrect tax return? } \\
\hline \multirow{3}{*}{ Valid } & yes & Frequency & Percent & Valid Percent & \multicolumn{2}{c|}{ Cumulative Percent } \\
\cline { 2 - 6 } & no & 85 & 77.3 & 77.3 & 100.0 \\
\cline { 2 - 6 } & Total & 25 & 22.7 & 22.7 & \\
\hline
\end{tabular}

The Table no. 1.12 depicts77.3\% respondents were aware that penalty is imposed if incorrect tax return is submitted, while only $22.7 \%$ did not know about it.

Table 1.13:-

\begin{tabular}{|c|c|c|c|c|c|}
\hline \multicolumn{6}{|c|}{ Are you aware of the new tax rate passed by the Finance Minister in the 2017 budget? } \\
\hline & & Frequency & Percent & Valid Percent & Cumulative Percent \\
\hline \multirow[t]{3}{*}{ Valid } & Yes & 74 & 67.3 & 67.3 & 67.3 \\
\hline & No & 36 & 32.7 & 32.7 & 100.0 \\
\hline & Total & 110 & 100.0 & 100.0 & \\
\hline
\end{tabular}

The Table no. 1.13 depicts67.3\% respondents were aware that of the new tax rate of 2017, while only $32.7 \%$ did not know about it.

Table 1.14:-

\begin{tabular}{|c|c|c|c|c|c|}
\hline \multicolumn{6}{|c|}{ Are you aware of tax saving methods/ schemes/ process? } \\
\hline & & Frequency & Percent & Valid Percent & Cumulative Percent \\
\hline \multirow[t]{3}{*}{ Valid } & Yes & 70 & 63.6 & 63.6 & 63.6 \\
\hline & No & 40 & 36.4 & 36.4 & 100.0 \\
\hline & Total & 110 & 100.0 & 100.0 & \\
\hline
\end{tabular}

The Table 1.14 depicts that, $63.64 \%$ percentage of respondents were aware of such schemes/ process, whereas $36.36 \%$ are not aware of these schemes. 
Table 1.15:-

\begin{tabular}{|l|l|r|r|r|r|}
\hline \multicolumn{2}{|c|}{ If yes, then in which schemes have you invested? } \\
\hline \multicolumn{2}{|l|}{} & Frequency & Percent & Valid Percent & $\begin{array}{c}\text { Cumulative } \\
\text { Percent }\end{array}$ \\
\hline \multirow{3}{*}{ Valid } & PPF & 40 & 36.4 & 36.4 & 36.4 \\
\cline { 2 - 6 } & ULIP & 17 & 15.5 & 15.5 & 51.8 \\
\cline { 2 - 6 } & Tax saving FD & 24 & 21.8 & 21.8 & 73.6 \\
\cline { 2 - 6 } & EPF & 11 & 10.0 & 10.0 & 83.6 \\
\cline { 2 - 6 } & NSC & 6 & 5.5 & 5.5 & 89.1 \\
\cline { 2 - 6 } & Infrastructure bonds & 9 & 8.2 & 8.2 & \\
\cline { 2 - 6 } & Tax saving mutual funds & 3 & 2.7 & 2.7 & \\
\cline { 2 - 7 } & Total & 110 & 100.0 & 100.0 & 100.0 \\
\hline
\end{tabular}

The Table 1.15 depicts that, the highest percentage of respondents invest in PPF i.e., 36.4\%, whereas the minimum investment were in tax saving mutual funds i.e., $2.7 \%$.

Table 1.16:-

\begin{tabular}{|l|l|r|r|r|r|}
\hline \multicolumn{2}{|c|}{ Where do you get your investment information? } \\
\hline \multirow{2}{*}{} & \multicolumn{2}{|c|}{ Frequency } & Percent & Valid Percent & $\begin{array}{c}\text { Cumulative } \\
\text { Percent }\end{array}$ \\
\hline \multirow{3}{*}{ Valid } & friends, relatives & 14 & 12.7 & 12.7 & 12.7 \\
\cline { 2 - 6 } & news papers & 23 & 20.9 & 20.9 & 33.6 \\
\cline { 2 - 6 } & Constants & 48 & 43.6 & 43.6 & 7.3 \\
\cline { 2 - 6 } & Tv ads & 8 & 7.3 & 15.5 & \\
\cline { 2 - 7 } & Internet & 17 & 15.5 & 100.0 & 100.0 \\
\cline { 2 - 7 } & Total & 110 & 100.0 & \\
\hline
\end{tabular}

The Table 1.16 depicts that, the highest percentage of respondents get there information from constants i.e., $43.64 \%$, whereas $7.24 \%$ get there investment information from TV ads.

Table 1.17:-

\begin{tabular}{|l|l|r|r|r|r|}
\hline \multicolumn{2}{|c|}{ What is your investment pattern/ } \\
\hline \multirow{2}{*}{} & \multicolumn{2}{|c|}{ Frequency } & Percent & Valid Percent & $\begin{array}{c}\text { Cumulative } \\
\text { Percent }\end{array}$ \\
\hline \multirow{3}{*}{ Valid } & monthly (SIP) & 61 & 55.5 & 55.5 & 55.5 \\
\cline { 2 - 6 } & once in six months & 20 & 18.2 & 18.2 & 73.6 \\
\cline { 2 - 6 } & once in a year & 8 & 7.3 & 19.1 & \\
\cline { 2 - 6 } & very rare & 21 & 19.1 & 100.0 & 100.0 \\
\cline { 2 - 7 } & Total & 110 & 100.0 & & \\
\hline
\end{tabular}

The Table 1.17 depicts that, the highest percentage of respondents invest in Monthly SIP i.e., 55.45\%, whereas the minimum investment done by respondents were in once a year i.e., 7.27\%

Table 1.18:-

What is the proportion of savings and expenditure in your earnings? savings: expenditure

\begin{tabular}{|c|c|c|c|c|c|}
\hline \multicolumn{6}{|c|}{ What is the proportion of savings and expenditure in your earnings? savings: expenditure } \\
\hline & & Frequency & Percent & Valid Percent & Cumulative Percent \\
\hline \multirow[t]{5}{*}{ Valid } & $10: 90$ & 36 & 32.7 & 32.7 & 32.7 \\
\hline & $20: 80$ & 48 & 43.6 & 43.6 & 76.4 \\
\hline & $30: 70$ & 4 & 3.6 & 3.6 & 80.0 \\
\hline & 40:60 & 22 & 20.0 & 20.0 & 100.0 \\
\hline & Total & 110 & 100.0 & 100.0 & \\
\hline
\end{tabular}

The Table no. 1.18 depicts, that $43.6 \%$ of respondents belong to 20:80 ratio of savings and expenditure, while only $3.6 \%$ belongs to $30: 70$ ratio. 
Table 1.19:-

\begin{tabular}{|l|l|r|r|r|r|}
\hline \multicolumn{2}{|c|}{ Type of investments? } & Valid Percent & $\begin{array}{c}\text { Cumulative } \\
\text { Percent }\end{array}$ \\
\hline \multirow{3}{*}{} & Frequency & Percent & 32.7 & 32.7 \\
\cline { 2 - 6 } & long term (greater than 3yr) & 36 & 32.7 & 44.5 & 77.3 \\
\cline { 2 - 6 } & medium term (1 to 3yr) & 49 & 44.5 & 22.7 & 100.0 \\
\cline { 2 - 6 } & short term (less than 1yr) & 25 & 22.7 & 100.0 & \\
\cline { 2 - 7 } & Total & 110 & 100.0 & & \\
\hline
\end{tabular}

The Table no. 1.19 depicts, that $44.5 \%$ of respondents invest in medium term, while $22.7 \%$ invest in short term duration.

Table 1.20:-

Out of your savings, what proportional of it is saved for the long-term, medium and short term?

\begin{tabular}{|l|l|r|r|r|r|}
\hline \multicolumn{1}{|c|}{} & Frequency & Percent & \multicolumn{1}{c|}{ Valid Percent } & Cumulative Percent \\
\hline \multirow{4}{*}{} & $10: 20: 70$ & 46 & 41.8 & 41.8 & 41.8 \\
\cline { 2 - 6 } & $20: 30: 50$ & 33 & 30.0 & 30.0 & 71.8 \\
\cline { 2 - 6 } & $30: 40: 50$ & 27 & 24.5 & 24.5 & 96.4 \\
\cline { 2 - 6 } & Other & 4 & 3.6 & 3.6 & 100.0 \\
\cline { 2 - 6 } & Total & 110 & 100.0 & 100.0 & \\
\hline
\end{tabular}

The Table no. 1.20 depicts, that $41.8 \%$ of respondents belong to 10:20:70 ratio of savings and expenditure, while only $24.5 \%$ belongs to $30: 40: 50$ other ratio.

Table 1.21:-

\begin{tabular}{|l|l|r|r|r|r|}
\hline \multicolumn{7}{|c|}{ Objectives of your investment } \\
\hline \multirow{3}{*}{} & Safety & Frequency & \multicolumn{1}{c|}{ Percent } & Valid Percent & Cumulative Percent \\
\cline { 2 - 6 } & Liquidity & 49 & 44.5 & 44.5 & 44.5 \\
\cline { 2 - 6 } & Return & 14 & 12.7 & 12.7 & 57.3 \\
\cline { 2 - 6 } & reliability & 20 & 18.2 & 18.2 & 75.5 \\
\cline { 2 - 6 } & low risk & 9 & 8.2 & 8.2 & 83.6 \\
\cline { 2 - 7 } & other factors & 10 & 9.1 & 9.1 & 92.7 \\
\cline { 2 - 7 } & Total & 8 & 7.3 & 100.0 & \\
\end{tabular}

The Table 1.21 depicts that, the main objective of respondents is Safety i.e., 44.55\%, whereas the minimum investment objective is $7.3 \%$ i.e., other factors.

Table 1.22:-

Is there a need for creating awareness among the public of Allahabad about the benefits of investing in tax

\begin{tabular}{|l|l|r|r|r|r|}
\multicolumn{2}{|c|}{} & \multicolumn{4}{c|}{ Saving schemes? } \\
\hline \multirow{3}{*}{ Valid } & Frequency & Percent & Valid Percent & Cumulative Percent \\
\cline { 2 - 6 } & yes & 85 & 77.3 & 77.3 & 77.3 \\
\cline { 2 - 7 } & No & 25 & 22.7 & 22.7 & 100.0 \\
\cline { 2 - 6 } & Total & 110 & 100.0 & 100.0 & \\
\hline
\end{tabular}

Table 1.23:-

Are there sufficient tax saving schemes investors educations and services centers in Allahabad?

\begin{tabular}{|c|c|c|c|c|c|}
\hline & & Frequency & Percent & Valid Percent & Cumulative Percent \\
\hline \multirow[t]{3}{*}{ Valid } & Yes & 32 & 29.1 & 29.1 & 29.1 \\
\hline & No & 78 & 70.9 & 70.9 & 100.0 \\
\hline & Total & 110 & 100.0 & 100.0 & \\
\hline
\end{tabular}

The Table no. 1.23 depicts $70.9 \%$ respondents agreed that there is a lack of tax education centers in Allahabad only $29.1 \%$ responded that there are enough tax education centers. 
Table 1.24:-

Do you accept the facts that investing in tax saving schemes will lead to the economic development?

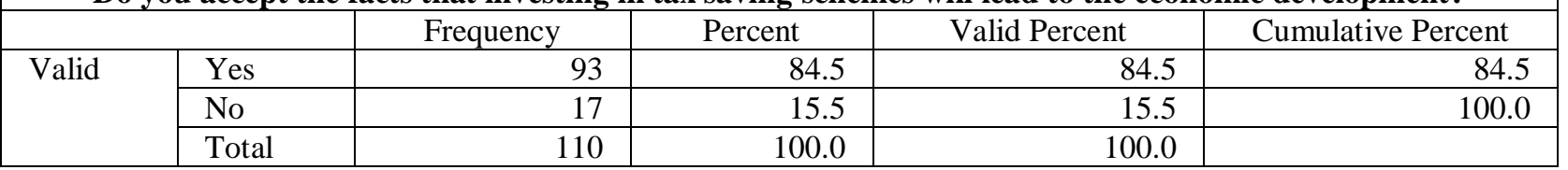

The Table no. 1.24 depicts that $84.5 \%$ respondents agreed investing in tax saving schemes will lead to the economic development while $15.5 \%$ disagreed to the question.

Table 1.25:-

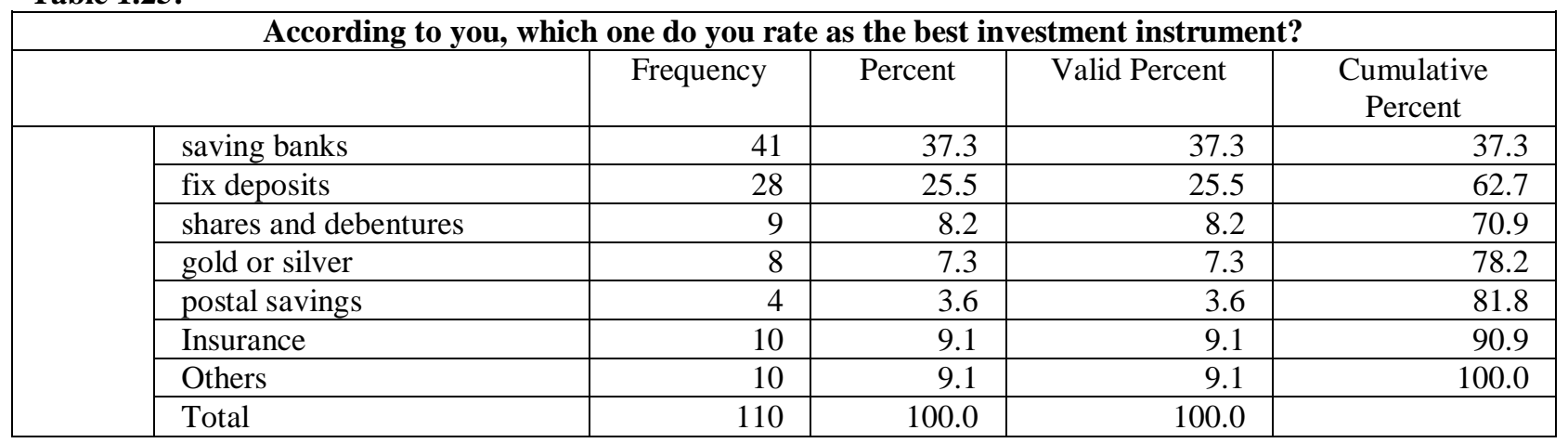

The Table 1.25 depicts that, the highest percentage of respondents invest in saving banks i.e., 37.27\%, whereas the minimum investment was in postal savings i.e., $3.64 \%$

\section{Conclusion:-}

The study is all about understanding the customer's awareness to the tax benefit schemes. If the customers know what are the ways by which there can avail the benefits of tax and in which sectors the can invest their money so that they get more tax reliefs. And also, to understand the investment pattern of customers towards these tax benefits schemes. The study shows working women are not aware of the tax rate which they are paying and surprisingly in Table $1.444 .2 \% 44.23 \%$ respondents were reluctant to know.

\section{Recommendations:-}

- Proper education of financial terms should be given to the working women.

- Government should take necessary steps for imparting education for improving financial literacy among working women.

- Establishment of knowledge centres for any queries related to tax saving schemes and investment option is required.

\section{Limitations of the study}

1. The present study is only related to the working women at Allahabad.

2. Most of the respondents were reluctant in sharing their personal information.

\section{References:-}

1. By, P., \& Jain pursuing, R. (2014). AN ANALYSIS OF INCOME AND INVESTMENT PATTERN OF WORKING WOMEN IN THE CITY OF AHMEDABAD. IRACST-International Journal of Research in Management \& TechnologyInternational Journal of Research in Management \& Technology, 4(46), 22499563. Retrieved from http://www.iracst.org/ijrmt/papers/vol4no62014/1vol4no6.pdf

2. Jisha, V. G., Go Mathi, V., Professor, A., \& Scholar, R. (2017). A Study on the Perception of Investment Pattern among Urban Working Women with Reference to Coimbatore City. International Journal of Engineering Science and Computing. Retrieved from http://ijesc.org/

3. Palil, M. R., Rusyidi, M., Akir, M., Fadillah, W., \& Ahmad, B. W. (2013). The Perception of Tax Payers on Tax Knowledge and Tax Education with Level of Tax Compliance: A Study the Influences of Religiosity. ASEAN Journal of Economics, Management and Accounting, 1(1), 118-129. Retrieved from http://fem.ipb.ac.id/miicema/e-journal2/wp-content/uploads/2015/09/8.pdf 
4. Sebastian, T., \& Appalla Raju, M. (n.d.). A Study On The Financial Literacy Of Professional Women In The District Of Ernakulum, Kerala. International Journal of Technology Enhancements and Emerging Engineering Research, 4(4). Retrieved from http://www.ijteee.org/final-print/july2016/A-Study-On-The-Financial-LiteracyOf-Professional-Women-In-The-District-Of-Ernakulum-Kerala.pdf 